\title{
Elevating Financial Literacy Among Non-Governmental Organizations (NGOs) Rulers: Cognitive Understanding of Financial Knowledge, Skills and Responsibility
}

\author{
Vani Tanggamani, Hamidah Bani, Azlina Rahim, Nor Ashikin Alias
}

To Link this Article: http://dx.doi.org/10.6007/IJARBSS/v11-i12/11872～DOI:10.6007/IJARBSS/v11-i12/11872

Received: 17 October 2021, Revised: 19 November 2021, Accepted: 30 November 2021

Published Online: 21 December 2021

In-Text Citation: (Tanggamani et al., 2021)

To Cite this Article: Tanggamani, V., Bani, H., Rahim, A., \& Alias, N. A. (2021). Elevating Financial Literacy Among Non-Governmental Organizations (NGOs) Rulers: Cognitive Understanding of Financial Knowledge, Skills and Responsibility. International Journal of Academic Research in Business and Social Sciences, 11(12), 1290-1297.

Copyright: (c) 2021 The Author(s)

Published by Human Resource Management Academic Research Society (www.hrmars.com) This article is published under the Creative Commons Attribution (CC BY 4.0) license. Anyone may reproduce, distribute, translate and create derivative works of this article (for both commercial and non0-commercial purposes), subject to full attribution to the original publication and authors. The full terms of this license may be seen at: http://creativecommons.org/licences/by/4.0/legalcode

Vol. 11, No. 12, 2021, Pg. 1290 - 1297

Full Terms \& Conditions of access and use can be found at http://hrmars.com/index.php/pages/detail/publication-ethics 


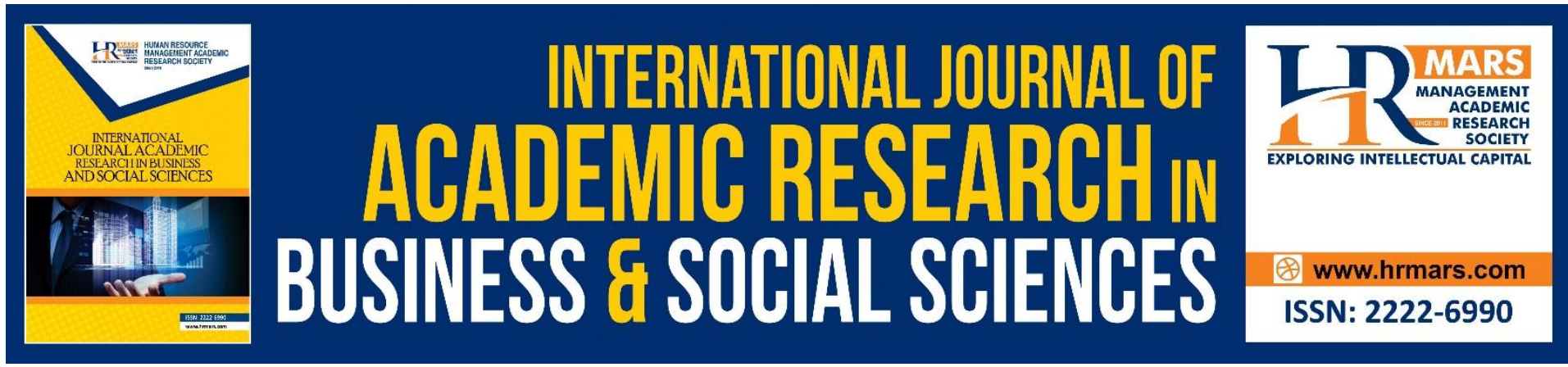

\title{
Elevating Financial Literacy Among Non- Governmental Organizations (NGOs) Rulers: Cognitive Understanding of Financial Knowledge, Skills and Responsibility
}

\author{
Vani Tanggamani, Hamidah Bani, Azlina Rahim, Nor Ashikin \\ Alias
}

Faculty of Accountancy, Universiti Teknologi MARA, 78000 Melaka, Malaysia

\begin{abstract}
There has been a rising interest in the financial literacy among the academician, community rulers, financial institutions, organization, and policymakers because it is vital part of everyday life for individuals and ability to provide for current and future financial needs. Recent surveys conducted by the Malaysia National Strategy for Financial Literacy 2019 2023 reported that one in every three Malaysians rated themselves to be of low financial knowledge due to low confidence regarding their own financial knowledge, especially low income households group category. Failure to embrace the culture of proper financial management is a major obstacle community development, particularly due to inadequate levels of financial literacy in the handling of financial matters. Given this environment, indepth knowledge of financial literacy is a must in order to improve financial well being of community through competitive and sustainable economy. Hence, the purpose of this study is to elevate the financial literacy among Non-governmental organizations (NGOs) rulers in Malaysia. The NGOs rulers playing an important role to empower a sustainable, competitive and prosperous communities. Therefore, the knowledge and skill in financial literacy seem to be a very important element in making the financial well-being of the communities. In large it may reduce poverty among those in the B40 category. In this context, this study is highly referred in cognitive understanding of financial knowledge, skills and responsibility of the group to be studied, giving emphasis on the planning and management of the community economic activities and development program. Exploratory sequential mixed method research design will be employed, which combined qualitative (interviews) and quantitative (questionnaires) to enhance financial literacy that is expected to develop a financially literate nation for the long term economic well being of the communities.
\end{abstract}

Keywords: Financial Literacy, Financial Well Being of the Communities, Financial Knowledge, Skills and Responsibility, NGOs Rulers. 


\section{Research Background \\ Problem Statement}

According to Malaysian Financial Literacy Survey 2020, surprising that many Malaysians are concerned about their financial position. Almost $70 \%$ of Malaysians are in need of financial literacy support. Financial knowledge, ability and attitude towards financial matters is known as financial literacy (Kamakia et al., 2017; Remund, 2010). It leads to sound decision making and enhance an individual's financial well-being.

The need for financial literacy is becoming inevitable, as it is the measurement of how well an individual can understand and use personal finance-related information (Allianz, 2017). Good financial literacy promotes good financial behaviour, which in turn, contributes to the growth of a county's economy and communities well being (Boisclair et al., 2017). The latest initiative from the Financial Education Network concerned with empowering financial literacy is the National Strategy for Financial Literacy 2019-2023, whereby every organization is committed to improving financial literacy among Malaysian by organizing various financial education initiatives.

Raising financial literacy of all Malaysians requires a systematic, sustained and coordinated approach that focuses on engendering long-term financial behavioural change (Engels et al., 2020; Boisclair et al., 2017). In view of Strategic Priorities and Action Plans of National Strategy for Financial Literacy 2019 - 2023, one of the important objective is to inform, educate and support Malaysians in practicing sound financial management, focus efforts on vulnerable segments of the society. This includes fostering good money management practices through community-based financial education and inculcate positive behaviour towards financial resilience.

Yet, it requires a strong financial literacy for effective implementation of policies and achievement of intended outcomes (Boisclair et al., 2017). When a leader is not well trained in financial literacy, poor financial decisions are made, leaves the door open for large potential reduction in the economic growth (Artavanis \& Kara, 2020). Therefore, in order to uphold economic growth, particularly in the era of Covid-19 global pandemic, financial literacy is one of the alternatives to improve financial knowledge and planning among NGOs rulers. The ultimate goal of elevating the financial literacy among NGOs rulers is to steer them through these challenges and help them emerge on stronger financial footing. Financial literacy is vital for NGOs rulers to make many financial decisions since most of the NGOs activities are the main source of income for communities. It's not just about surviving, but it's about achieving real financial outcomes for the benefits of the society (Mohamed, 2017).

However, the importance of financial literacy is not widely emphasized by NGOs rulers for economic performance in Malaysia (Rashid et al., 2019), even though financial literacy is one of critical element influencing a leader's ability to manage finances effectively (Ali et al., 2014; Rashid et al., 2019). Strong financial literacy will enable the leader to manage available financial resources efficiently and effectively in a way that will increase the ability of the government to provide more services to the community (Mohamed, 2017). It is the Government's hope to improve Malaysian's financial well being and contribute to the growth of a county's economy. 
Therefore, evidence related to financial literacy among NGOs rulers, especially cognitive understanding of financial knowledge, skills and responsibility is still needed. Increasing their knowledge of financial literacy, which will affect their financial responsibility and financial behaviour, is expected to benefit them in making informed judgments and effective decisions regarding the use and management of money. In other words, not only benefits their NGOs, but at a macro level it affects a nation as a whole. Thus, this study is to be conducted to elevate the financial literacy among NGOs rulers, particularly on their cognitive understanding of financial knowledge, skills and responsibility.

\section{Research Questions}

(i) Why financial literacy is important for NGO rulers?

(ii) How's the cognitive understanding of financial literacy can be improved?

\section{Objective (s) of the Research}

(i) To elevate financial literacy among NGO rulers as to promote responsible behaviour and rational attitudes

(ii) To improve the level of financial knowledge, skills and responsibility among NGO rulers that can lead towards sound financial decisions.

\section{Literature Reviews}

\section{Financial Literacy and Financial Well Being}

Financial literacy is about the awareness, knowledge, skills, attitude and behaviour necessary to make sound financial decisions, where financial well being means lead a meaningful, content and sustainable life free from constant financial worries, able to withstand temporary income shocks, changes in life circumstances and emergencies without financial burden (OECD, 2013). Financial literacy refers to an individual's knowledge of basic financial concepts, and also about the management of expected and unexpected expenses (Artavanis \& Sara, 2020). Understanding what financial literacy is and why it's important to an orgnization helps you develop the skills necessary to increase profits by managing the financial aspects of your business a person with financial acumen is able to evaluate the impact of a business decision on the business' financial statements, and financial wellbeing in the long term (Engels et al., 2020).

Financial literacy is essential to impart financial knowledge, skills and responsibility to promote positive financial behaviour among the NGOs rulers, thus encourage self and NGOs sustainability as well to improve financial well being of communities. According to Boisclair et al (2017), the elements of financial literacy is a particular kind of cognitive understanding that affect the ability to make informed financial decisions after clarifying and understanding the nature, risks and benefits of various financial information. Meanwhile, Orton (2007), defined financial literacy can be divided into three important elements; (i) financial knowledge and understanding, (ii) financial skills and competence, and (iii) financial responsibility.

\section{Financial Knowledge and Understanding}

According to Aydin \& Selcuk (2018), financial knowledge is a influential factor in the formation of individual financial literacy. Individual who were given financial knowledge, proving that financial literacy is influenced by financial knowledge and understanding (Frisancho, 2019; Fan \& Chatterjee, 2018). Financially literate individuals have the knowledge and greater 
understanding to make financial decisions (Paskelian et al., 2019). This proves that intervention through financial education improves financial literacy.

\section{Financial Skills and Competence}

According to Frisancho (2019), there is a significant relationship between financial knowledge and financial literacy. The knowledge of an individual who received financial-related training is increased compared to those who did not receive any financial related training. The development of any training or workshop that is specially designed to elevate financial literacy and inculcate financial skills and competence by policymakers and organization rulers are able to form individual skills to manage finances while improving individual financial skills through participation in programs, financial seminars, and financial related basic courses (Aydin \& Selcuk, 2018).

\section{Financial Responsibility}

There is a positive relationship between financial responsibility of individuals who are involved in financial learning more often (Wagner, 2015). As indicated by Mohamed (2017); Agnew (2018), the interaction between financial literacy and financial attitude showed a positive relationship and affects financial responsibility. Therefore, there is a significant relationship between financial responsibility and financial literacy.

\section{NGOs and Financial Well Being Society}

Community development is an important aspect of a country's political and economic stability. In countries with emerging and developing economies such as Malaysia, rural populations constitute the majority of citizens (Rashid et al., 2019; Allianz, 2017). The government agencies such as the Ministry of Rural and Regional Development have allocated more resources to finance projects in the villages, particularly those economic activities (Ministry of Rural Development, 2019). The government efforts to development planning at a village level encourage and empower village people to plan and implement development projects according to their needs and aspirations. Governments worldwide are beginning to recognize the challenge of sustainability, and this term is being addressed in public policy discussions. Any one government cannot work in this area alone; it is imperative to work with other governments in order to address the issue in a global context. According to a GlobeScan poll of experts, the leading role in achieving sustainability will be played by business (35\%), followed by NGOs (30\%), and governments (24\%) (Blakely \& Leigh, 2013). Consequently, government had formed the NGOs for community development, thus NGOs are becoming the medium for the community to voice out or be the one who lend their hand to help the community around them. NGOs play an important role to help the people in the community to have a better health in the future. Therefore, according to Rashid (2019), any community development rulers must be committed, dedicated, knowledgeable, skilful and optimistic to continuously to develop the community, thereby supporting poverty reduction and economic growth. It is therefore critical, and there is great value to be gained, by coordinating community development initiatives that contribute to sustainable economic well being. Therefore, enhancing financial acumen in financial management is vital importance to improve community economic well-being through better financial decision making among NGO rulers. Having enough financial knowledge and abilities resulted in appropriate and informed decisions (Hilgert et al., 2003), which are important not only for individuals but also on community management level. As such, Increased reliance on NGO rulers ' financial 
acumen in financial planning, can free up resources so that the Ministry of Rural Development (KPLB) can facilitate more financial grants in achieving sustainable economic development

\section{Methodology \\ Description of Methodology}

This study focuses on selected NGO Rulers in Malaysia which includes leaders and senior representatives. The objective is to elevate financial literacy by focusing on the following variables or determinants namely (i) demographic characteristics, (ii) financial knowledge and understanding, (iii) financial skills and competence, and (iv) financial responsibility of the group to be studied. These four variables are expected to influence the financial literacy of the NGOs rulers. The demographic characteristics include age, gender, and background. Financial knowledge and understanding may include tertiary and higher-level education, and relevant experiences. Financial skills and competence includes relevant training and workshop attended. Financial responsibility includes attitude, social influence, emotion and challenges in financial matters. Furthermore, all of these variables will be employed to elevate the financial literacy of the said group. Exploratory sequential mixed method research design, which combined qualitative (interviews) and quantitative (questionnaires) data will be employed in this study. Data analysis in qualitative research focusing on the process of systematically searching and arranging the interview transcripts. The interview sessions is essential to get in-depth understanding on issues related to financial knowledge and skills among participants. The interview process will be recorded and transcribed by using thematic analysis, where to know exactly what is current practice versus what is supposed to be. Similar items from the interview results will be used as a construct item in the preparation of preliminary questionnaire, as to collect data and information about the four variables mentioned earlier. For sampling, researchers will choose probability sampling techniques which is stratified random sampling. It will starts off by dividing a population into groups with similar attributes. Then a random sample is taken from each group. The group includes leaders and senior representatives in NGOs. Next, the research activities were on data analysis. The input data will be analyzing using SEM AMOS. The information gathered can be used to elevate financial literacy which is important for sustainable financial well-being communities in Malaysia. Next, discussions and implications of the results will be presented and a suggestion for improvement will also be discussed. Finally, this study provided conclusion and recommendations for cognitive understanding of financial literacy based on research finding.

\section{Relevance to Government Policy, if any}

Rural Development Policy (DPLB) 2030 that was launched on June 27, 2019 by Prime Minister Tun Dr Mahathir Mohamad, provides a comprehensive roadmap and overall development strategy in line with the United Nations Sustainable Development Goals. The DPLB formulation was made in accordance with current policies including the National Rural Physical Planning Policy 2030, the 11th Malaysia Plan Mid-Term Review (11MP), the Rural Development Hope Plan 2018-2023 and the Sustainable Development Goals. The implementation of the DPLB 2030 must be driven by the people in the rural areas, especially in aspects involving economic growth. Therefore, the study proposes to improve financial literacy that will benefits the communities. The enhancement of financial literacy among NGO rulers would able to enhance the financial planning and decision making among NGO rulers, thus create a sustainable, competitive and prosperous society. Thus, definitely will help the 
government to achieve the development proposals of the society in the form of projects, programmes and economic activities.

\section{Theoretical and Practical Contributions}

This paper will contribute several theoretical and practical contributions in the fields of financial literacy among NGO rulers. Firstly, our findings will elevate the financial literacy, particularly among NGO rulers as well as to lead towards financial well being communities. This is in line with the Rural Development Policy (DPLB) 2030 and National Strategy for Financial Literacy 2019 - 2023, to promote financial behaviour and rational attitudes for the happiness and well being of society.

Secondly, this paper means to improve the level of financial knowledge, skills and responsibility among NGO rulers with respect to ability to meet current and ongoing financial obligations in order to make the right financial decisions. This is very essential because the financial decisions NGOs rulers make today can have lasting effects on our communities wellbeing. By improving the ability, capability and desire of NGOs rulers to take charge of their financial destinies, stronger communities are fostered to create a brighter future for all and not just a few.

Finally, the paper will giving emphasis on the NGOs rulers in Malaysia to promote financial literacy for wellbeing of communities, particularly those economic activities that potentially be highly beneficial to a range of households.

Improving financial literacy among NGOs rulers requires a systematic, sustained and coordinated approach that focuses on engendering long-term behavioural change.Therefore, this paper is a key to empowering NGOs rulers with better financial literacy are able to use their existing financial knowledge and skills to take appropriate actions involving financial planning and activities that could lead towards good financial behaviour.

\section{Acknowledgements}

The authors would like to express their appreciation to Universiti Teknologi MARA Cawangan Melaka for the financial support provided in accomplishing this research under the TEJA Internal Grant Scheme 2021 (GDT2021/1-19).

\section{References}

Agnew, S. (2018). Empirical measurement of the financial socialisation of children by parents. Young Consumers 19(4): 421-431.

Ali, A., Rahman, M. S. A., \& Bakar, A. (2014). Financial Literacy and Satisfaction in Malaysia : Pilot Financial Literacy and Satisfaction in Malaysia : Pilot Study. International Journal of Trade, Economic and Finance, 4(5), 320-323.

Allianz. (2017). When will the penny drop? Money, financial literacy and risk in the digital age. Retrieved from http://gflec.org/initiatives/money-finlit-risk/

Artavanis, N., and Kara, S. (2020). "Financial Literacy and Student Debt." European Journal of Finance 26 (4-5): 382-401.

Aydin, A. E., \& Selcuk, E. A. (2018). An investigation of financial literacy, money ethics and time preferences among college students 2017(113).

Boisclair, D., Lusardi, A., \& Michaud, P. C. (2017). Financial literacy and retirement planning in Canada. Journal of Pension Economics \& Finance, 16(3), 277-296. 
Blakely, E. J., \& Leigh, N. G. (2013). Planning local economic development. Sage.

Bryant, J. H., Madhavan, G., Oakley, B., Green, D., Koon, D., \& Low, P. (2013). Economic Growth and Sustainability Rooted in Financial Literacy. In Practicing Sustainability; Springer: New York

Fan, L., \& Chatterjee, S. (2018). Application of situational stimuli for examining the effectiveness of financial education: A behavioral finance perspective. Journal of Behavioral and Experimental Finance 17: 68-75

Frisancho, V. (2019a). The impact of financial education for youth. Economics of Education Review(July): 101918.

Hilgert, M., Hogarth, J., \& Beverley, S. (2003). Household financial management: The connection between knowledge and behaviour. Fed. Res. Bull. 89, 309-322

Kamakia, M. G., Mwangi, C. I., \& Mwangi, M. (2017). Financial Literacy and Financial Wellbeing of Public Sector Employees: A Critical Literature Review. European Scientific Journal, ESJ, 13(16), 233

Meier, S., \& Sprenger, C. D. (2013). Discounting financial literacy: Time preferences and participation in financial education programs. Journal of Economic Behavior \& Organization, 95, 169-174. National Strategy for Financial Literacy 2019-2023

Mohamed, N. A. (2017). Financial socialization: a cornerstone for young employees' financial well-being. Reports on Economics and Finance 3(1): 15-35.

OECD. (2013). Improving Financial Education Effectiveness through Behavioural EconomicsOECD Key Findings and Way Foreward; OECD: Paris, France.

Orton, L. (2007). Financial Literacy: Lessons from International Experience; Canadian Policy Research Networks: Ottawa, ON, Canada

Paskelian, O., Jones, K., Bell, S., \& Kao, R. (2019). Financial Literacy and Behavioral Biases among Traditional Age College Students. Accounting and Finance Research 8(1).

Rashid, M. F., Misnan, S. H., \& Samsudin, N. A. (2019). Measuring The Determinants For Differentiation In Village Economic Performance In Rural Malaysia. 4th International Conference on Rebuilding Place. The European Proceedings of Multidisciplinary Sciences

Remund, D. (2010). Financial literacy explicated: The case for a clearer definition in an increasingly complex economy. The Journal of Consumer Affairs, 44, 2, 276-295.

Wagner, J. (2015). An Analysis Of The Effects Of Financial Education On Financial Literacy And Financial Behaviors. 